\title{
Cases of enteric fever secondary to gastrointestinal infections
}

\section{Gastrointestinal enfeksiyonlara sekonder enterik ateş vakaları}

\author{
Tuğba GÜLER ${ }^{1}$, Burcu VOLKAN ${ }^{2}$, Soner Sertan KARA ${ }^{3}$, Mehtap Hülya ASLAN ${ }^{4}$, Ali FETTAH ${ }^{1}$, Özde Nisa TÜRKKAN $^{1}$
}

\begin{abstract}
Acute gastroenteritis is one of the most prevalent infectious diseases in childhood. It constitutes one of the major causes of morbidity and mortality among children under 5 years of age. Although most cases of acute gastroenteritis in children are selflimited and treated with only supportive therapy, clinical deterioration can sometimes be observed during the clinical course. Persistence of high fever or a second peak secondary to diminished fever with no obvious source in children with gastroenteritis should raise suspicion of secondary bacteremia. In this case report we have reviewed two cases of enteric fever with acute gastroenteritis secondary to Clostridium difficile and rotavirus gastroenteritis.
\end{abstract}

Keywords: Clostridium difficile, rotavirus, enteric fever, gastrointestinal infections

\begin{abstract}
öz
Akut gastroenterit, çocukluk çağındaki en yaygın enfeksiyon hastalıklarından biridir. Beş yaş altındaki çocuklar arasında morbidite ve mortalitenin major nedenlerinden birini oluşturur. Çocuklardaki birçok akut gastroenterit vakası kendini sınırlayan ve yalnızca destek tedavisi ile tedavi edilir olsa da klinik seyir esnasında vakalarda kötüleşme gözlenebilir. Gastroenteritli çocuklarda belli hiçbir kaynak olmadan inatçı ateş ya da azalan ateşe sekonder pik, sekonder bakteriyemi şüphesini artırmalıdır. Bu vaka raporunda, Clostridium difficile ve rotavirüs gastroenteritine sekonder iki akut gastroenteritli enterik ateş vakasını gözden geçirdik.
\end{abstract}

Anahtar kelimeler: Clostridium difficile, rotavirüs, enteric ateş, gastrointestinal enfeksiyonlar

\section{INTRODUCTION}

Acute gastroenteritis (AGE) is described as a decline in stool density and/or increasing in the frequency of evacuations with or without vomiting, and is a common infectious disease mostly seen in childhood. It remains one of the major causes of morbidity and mortality among children under 5 years of age $\mathrm{e}^{1}$. Although gastroenteritis limits itself and is a mild disease, it is also a frequent cause of hospitalization ${ }^{2}$. Viruses are leading causes of AGE, and rotavirus is the main pathogenic agent of viral gastroenteritis in infants and young children ${ }^{3}$. Bacterial agents such as Clostridium difficile may be responsible for AGE in childhood which is mostly a nosocomial pathogen, resulting in a spectrum of intestinal diseases ranging from asymptomatic carriage and mild diarrhea to potentially fatal pseudomembranous colitis. In pediatric population, epidemiological studies demonstrated a change in the epidemiologic pattern of C. difficile infections, showing a two-fold increase within the last 5 years, but the incidence of severe complications did not increase ${ }^{2-4}$.

Clinical syndromes caused by Salmonella species in humans are basically grouped as enteric or typhoid fever caused by Salmonella typhi or S.paratyphi, with a spectrum of clinical syndromes including diarrheal disease caused by a large number of nontyphoid salmonellae (NTS) ${ }^{5}$.

Received: 07.02.2017

Accepted: 04.05.2017

${ }^{1}$ Department of Pediatrics, Erzurum Regional Training and Research Hospital, Erzurum, Turkey

${ }^{2}$ Department of Pediatric Gastroenterology, Erzurum Regional Training and Research Hospital, Erzurum, Turkey

${ }^{3}$ Department of Pediatric Infectious Diseases, Erzurum Regional Training and Research Hospital, Erzurum, Turkey

${ }^{4}$ Department of Microbiology, Erzurum Regional Training and Research Hospital, Erzurum, Turkey

Yazışma adresi: Tuğba Güler, Erzurum Regional Training And Research Hospital, Department of Pediatrics, Erzurum, Turkey

e-mail: mcanguler@yahoo.com 
Although most AGE cases in children are self-limited, and treated with only supportive therapy, clinical deterioration can sometimes be observed during the clinical course. Clinical and laboratory findings compatible with a severe bacterial infection should alert physicians about the possibility of secondary bacterial infections. We present two cases of enteric fever secondary to $C$. difficile and rotavirus gastroenteritis.

\section{CASE REPORTS}

Case 1: A 2 year-old boy was admitted to our hospital with fever, vomiting, and mucoid defecation within previous 3 days. His body temperature was $39^{\circ} \mathrm{C}$, pulse rate $120 / \mathrm{min}$, blood pressure $90 / 60 \mathrm{mmHg}$, and respiratory rate $50 / \mathrm{min}$. Moderate dehydration, hepatomegaly ( $4 \mathrm{~cm}$ below the costophrenic margin) and splenomegaly $(3 \mathrm{~cm}$ below the costophrenic margin) were observed. Laboratory examinations results were as follows: white blood cell count, $15 \times 10^{9} / \mathrm{L}$ (neutrophil count $9 \times 10^{9} / \mathrm{L}$ ); hemoglobin, $8.8 \mathrm{~g} / \mathrm{dL}$, platelet count, $78,000 \times 10^{9} / \mathrm{L}$; C-reactive protein (CRP) $19 \mathrm{mg} / \mathrm{dl}$ (normal; <5 mg/dl), and negative direct Coomb's test. Left shift and toxic granulation were observed in peripheral blood smear.

Serum biochemistry was normal, except for albu$\min 2.7 \mathrm{~g} / \mathrm{dl}$, and D-dimer, $3.41 \mu \mathrm{g} / \mathrm{ml}(0-0.55)$ while activated partial thromboplastin time (APTT) 19.4 (21-35), prothrombin time (PT) 14.3 (10.5-14.9) and International Normalized Ratio (INR) 1.16 (0.8-1.2) were within normal limits. Stool examinations for adenovirus and rotavirus antigens were negative. Treatment was started with ceftriaxone $(75 \mathrm{mg} / \mathrm{kg} /$ day) and vancomycin (45 mg/kg/day). Oral metronidazole (30 mg/kg/day) was added to treatment following positive $C$. difficile toxin A-B results and was maintained for 10 days. Intravenous immunoglobulin and erythrocyte suspension were used for resistant anemia and thrombocytopenia due to probable disseminated intravascular coagulopathy. Both blood and stool cultures yielded S. typhi strains which were sensitive to ceftriaxone and amikacin. Vancomycin treatment was stopped. Immunological examination, and evaluation of immunoglobulin levels, lymphocyte subgroups, and interferon- $\gamma$ and IL-12-binding receptor levels revealed no immunodeficiency. On the eighth day of the treatment, clinical improvement, negative control blood culture, and normal laboratory values were observed. He was discharged on the $14^{\text {th }}$ day of the antibiotic therapy.

Case 2: An 8 month-old boy presented with a 10-day history of fever and watery diarrhea. His vital signs and physical examination findings were unremarkable. White blood cell count was $10.3 \times 10^{9} / \mathrm{L}$, hemoglobin level $11.8 \mathrm{~g} / \mathrm{dl}$, platelet count $392,000 \times 10^{\%} / \mathrm{L}$, and CRP $2.7 \mathrm{~g} / \mathrm{dl}$. Serum biochemistry was normal. Rotavirus antigen was detected at stool examination. Intravenous fluid replacement was started while monitoring oral intake. Two days later, fever increased to $39.5^{\circ} \mathrm{C}$. Blood and stool culture were taken, and ceftriaxone therapy $(75 \mathrm{mg} / \mathrm{kg} /$ day) was started in case of secondary bacteremia. On the second day of the antibiotic treatment, his fever diminished and diarrhea regressed. No growth was observed in stool culture, while his blood culture yielded S. typhi, which was sensitive to ceftriaxone. Immunological investigation (immunoglobulin levels, lymphocyte subgroups, and interferon- $\gamma$ and IL-12-binding receptor levels) was normal. Antibiotic treatment was given for 14 days and he was discharged with negative blood cultures and without symptoms.

\section{DISCUSSION}

We have described two cases of gastroenteritis complicated with secondary Salmonella bacteremia. The hallmark of these secondary bacteremia cases was increased body temperature with no apparent source. Bacteremia following AGE is well-documented. Systemic manifestations (bacteremia, sepsis, and involvement of other organs like meninges, bones and lungs,) can complicate gastrointestinal infections caused by Yersinia, Shigella, Salmonella, and Campylobacter spp. ${ }^{2}$. In previous studies the prevalence rates of bacteremia secondary to gastroenteritis have been reported to range between 0.32 , and $1.3 \% 6,7$. Typhoid (enteric) fever is an acute and 
often life-threatening febrile disease caused by Salmonella enterica serotype typhi, and it is a significant public health concern especially in low and middleincome countries 5 . Typhoid fever affects nearly 21 million people each year, resulting in 200,000 to 600,000 deaths annually 8 . The case-fatality rate in inappropriate antibiotic using patients is $10-30 \%{ }^{9}$. Consumption of food or drink contaminated with feces is generally responsible for the transmission of $S$. typhi and, S. paratyphi A. and Salmonella spp., which cause several clinical manifestations, ranging from AGE to typhoid fever and bacteremia ${ }^{10}$. Data regarding the prevalence of secondary enteric fever are limited in number. Torrey et al. ${ }^{11}$ reported a prevalence of non-typhoidal Salmonella bacteremia of $6.5 \%$ in children with AGE due to Salmonella spp. Similarly, our first patient experienced salmonella gastroenteritis secondary to enteric fever.

In our first case, $C$. difficile toxin $A-B$ was detected, and the patient was treated accordingly. Although $C$. difficile infection (CDI) is an etiological agent of hospital-associated gastrointestinal illness with substantial morbidity and mortality, community-acquired, and nosocomial infection rates are increasing among children ${ }^{12}$. Symptoms of CDI are very diverse and range from an asymptomatic carrier stage to lifethreatening events, such as toxic megacolon. While it generally presents with mild to moderate, nonbloody diarrhea, and lower abdominal cramping, severe $\mathrm{CDI}$ causes systemic symptoms, like abdominal pain and distention, watery diarrhea and fever ${ }^{13}$. CDI results from normal colonic flora alteration then colonization and subsequent proliferation of the organism and expression of its toxin due to inappropriate antibiotic use ${ }^{12-14}$. Other risk factors for CDI are exposure to $C$. difficile, exposure to gastric acid suppressing agents, underlying illnesses such as inflammatory bowel diseases, malignancies, immunodeficiencies, hematopoietic stem cell transplants and solid organ transplants ${ }^{12}$. C. difficile or its toxin in stool can represent colonization, particularly in infants and younger children, and positive results should therefore be evaluated with caution ${ }^{15}$. Our patient had no history of antibiotic exposure and no other risk factors.
Despite the possibility of colonization and antibiotic treatment not being completely appropriate, he was given oral metronidazole due to a deteriorating clinical picture. Diagnosis of CDI typically relies on a high index of clinical suspicion and laboratory confirmation in stool. CDI can be confirmed by the presence of toxins $A$ and $B$ in the stool sample, anaerobic stool culture, and polymerase chain reaction. Toxin detection in the stool has a sensitivity of $70-80 \%$ due to the large number of false negatives ${ }^{13}$. We diagnosed CID in our patient based on a positive stool test for C. difficile toxin. Patients with non-severe CDI can be treated with oral metronidazole for 10 days and severe cases should receive oral vancomycin or oral fidaxomicin ${ }^{16}$.

Rotavirus gastroenteritis generally limits itself in otherwise healthy children. Despite the high frequency of rotavirus gastroenteritis, secondary bacteremia in the course of the illness has rarely been report$\mathrm{ed}^{6}$. Although its exact mechanism is not known, it is thought that infected enterocytes become more unprotected to bacterial invasion as a consequence of intestinal epithelium dysfunction caused by rotavirus $^{17}$. Bacterial translocation induced by the damage to the intestinal mucosa occurs later in the course of the disease. In the second patient, rotavirus gastroenteritis with Salmonella bacteremia was diagnosed and treated successfully.

The first line treatment options in typhoid fever is chloramphenicol, ampicillin, and trimethoprimsulfamethoxazole. However, newer quinolones and third generation cephalosporins are associated with higher cure rates ${ }^{18}$. Despite appropriate treatment, $2-4 \%$ of the infected children may relapse after initial clinical response ${ }^{18}$. In both of our cases, the bacteria were sensitive to empirically started ceftriaxone, and neither patient developed relapse or complication. Disseminated infections such as bacteremia due to $S$. typhi after AGE are not a frequent condition in immunocompetent patients ${ }^{19}$. Nevertheless, immunological investigations of both patients were normal. 


\section{CONCLUSION}

Enteric fever is a serious clinical condition that pediatricians may well encounter. Salmonella typhi bacteremia secondary to AGE is probably possible although it is rarer than other bacteria, management of these cases is similar. Persistence of high fever or a second peak during diminished fever with no obvious source in children with gastroenteritis should raise suspicion of secondary bacteremia. The first step is consideration of prompt and rapid start of antibiotic treatment after blood cultures are taken.

\section{REFERENCES}

1. Piescik-Lech M, Shamir R, Guarino A, Szajewska H. Review article: the management of acute gastroenteritis in children. Aliment Pharmacol Ther 2013;37(3):289-303. https://doi.org/10.1111/apt.12163

2. Ciccarelli S, Stolfi I, Caramia G. Management strategies in the treatment of neonatal and pediatric gastroenteritis. Infect Drug Resist 2013;6:133-161.

3. Lowenthal A, Livni G, Amir J, et al. Secondary bacteremia after rotavirus gastroenteritis in infancy. Pediatrics 2006;117(1):224-226. https://doi.org/10.1542/peds.2005-0177

4. Hookman P, Barkin JS. Clostridium difficile associated infection, diarrhea and colitis. World J Gastroenterol 2009;15(13):1554-1580. https://doi.org/10.3748/wjg.15.1554

5. Gordon MA. Salmonella infections in immunocompromised adults. J Infect 2008;56(6):413-422. https://doi.org/10.1016/j.jinf.2008.03.012

6. Gozmen S, Sukran Gozmen K, Apa H, et al. Secondary bacteremia in rotavirus gastroenteritis. Pediatr Infect Dis J 2014;33(7):775-777. https://doi.org/10.1097/INF.0000000000000324

7. Scheier $E$, Aviner $S$. Septicemia following rotavirus gastroenteritis. Isr Med Assoc J 2013;15(3):166-169.

8. Farmakiotis $D$, Varughese $J$, Sue $P$, et al. Typhoid fever in an inner city hospital: a 5-year retrospective review. J Travel Med 2013;20(1):17-21.

https://doi.org/10.1111/j.1708-8305.2012.00665.x

9. Buckle GC, Walker CL, Black RE. Typhoid fever and paratyphoid fever: systematic review to estimate global morbidity and mortality for 2010. J Glob Health 2012;2(1):010401. https://doi.org/10.7189/jogh.01.010401

10. Uzuner N, Arici A, Yilmaz E, et al. Typhoid fever with severe pancytopenia. Gazi Med J 2002;13:191-193.

11. Torrey S, Fleisher G, Jaffe D. Incidence of salmonella bacteremia in infants with salmonella gastroenteritis. J Pediatr 1986;108:718-721. https://doi.org/10.1016/S0022-3476(86)81050-2

12. Tamma PD, Sandora TJ. Clostridium difficile infection in children: current state and unanswered questions. J Pediatric Infect Dis Soc 2012;1(3):230-243. https://doi.org/10.1093/jpids/pis071

13. Honda H, Dubberke ER. Clostridium difficile infection: a reemerging threat. Mo Med 2009;106(4):287-291.

14. Kazanowski M, Smolarek S, Kinnarney F, Grzebieniak Z. Clostridium difficile: epidemiology, diagnostic and therapeutic possibilities-a systematic review. Tech Coloproctol 2014;18(3):223-232. https://doi.org/10.1007/s10151-013-1081-0

15. González-Del Vecchio M Á-UA, Marin M, Alcalá L, et al. Significance of clostridium difficile in children less than 2 years of age: a case-control study. Pediatr Infect Dis J 2016;35(3):281285 https://doi.org/10.1097/INF.0000000000001008

16. Debast SB, Bauer MP, Kuijper EJ, Committee. European society of clinical microbiology and infectious diseases: update of the treatment guidance document for clostridium difficile infection. Clin Microbiol Infect 2014;20 Suppl 2:1-26. https://doi.org/10.1111/1469-0691.12418

17. Ciftci E, Tapisiz A, Ozdemir H, et al. Bacteraemia and candidaemia: a considerable and underestimated complication of severe rotavirus gastroenteritis. Scand J Infect Dis 2009;41(11-12):857-861. https://doi.org/10.3109/00365540903214280

18. Bhutta ZA. Current concepts in the diagnosis and treatment of typhoid fever. BMJ 2006;333(7558):78-82. https://doi.org/10.1136/bmj.333.7558.78

19. Kara SS, Polat M, Tapisiz A, et al. Trauma associated acute navicular salmonella osteomyelitis. J Clin Anal Med 2016;7(2):279-281. 